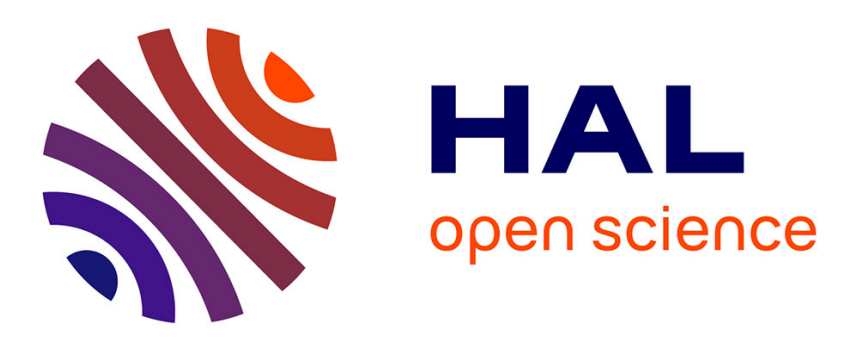

\title{
Study of the acarofauna of native bumblebee species (Bombus) from Argentina
}

\author{
Matias Maggi, Mariano Lucia, Alberto Abrahamovich
}

\section{To cite this version:}

Matias Maggi, Mariano Lucia, Alberto Abrahamovich. Study of the acarofauna of native bumblebee species (Bombus) from Argentina. Apidologie, 2011, 42 (3), pp.280-292. 10.1007/s13592-011-0018-8 . hal-01003549

\section{HAL Id: hal-01003549 \\ https://hal.science/hal-01003549}

Submitted on 1 Jan 2011

HAL is a multi-disciplinary open access archive for the deposit and dissemination of scientific research documents, whether they are published or not. The documents may come from teaching and research institutions in France or abroad, or from public or private research centers.
L'archive ouverte pluridisciplinaire HAL, est destinée au dépôt et à la diffusion de documents scientifiques de niveau recherche, publiés ou non, émanant des établissements d'enseignement et de recherche français ou étrangers, des laboratoires publics ou privés. 


\title{
Study of the acarofauna of native bumblebee species (Bombus) from Argentina
}

\author{
Matias MaGGi ${ }^{1,3}$, Mariano LuCiA ${ }^{2,3}$, Alberto H. Abrahamovich ${ }^{2,3}$ \\ ${ }^{1}$ Laboratorio de Artrópodos, Facultad de Ciencias Exactas y Naturales, Universidad Nacional de Mar del Plata, \\ Funes, 3350, 7600, Mar del Plata, Argentina \\ ${ }^{2}$ División Entomología, Museo de La Plata, Paseo del Bosque, 1900, La Plata, Argentina \\ ${ }^{3}$ CONICET, Consejo Nacional de Investigaciones Científicas y Técnicas, Rivadavia, 1917, C1033AJ, Buenos \\ Aires, Argentina
}

Received 23 December 2009 - Revised 23 April 2010 - Accepted 4 May 2010

\begin{abstract}
A total of 382 bumblebee specimens were examined: Bombus atratus $(n=310)$, Bombus morio $(n=42)$, Bombus bellicosus $(n=16)$, Bombus opifex $(n=8)$, and Bombus tucumanus $(n=6)$. Prevalence, abundance, and intensity of mite infestation for each Bombus species and for each caste were recorded. The different mite species infesting bumblebee specimens were: Kuzinia laevis (Dujardin), Kuzinia americana (Delfinado and Baker), Scutacarus acarorum (Goeze), Pneumolaelaps longanalis (Hunter and Husband), Pneumolaelaps longipilus (Hunter), Tyrophagus putrescentiae (Schrank), and Parasitellus fucorum (De Geer). Numbers of mites varied enormously and ranged from one individual to over 200 per bumblebee. Kuzinia mites were represented by the phoretic forms (hypopi). Only nymphs of $P$. fucorum were recorded. Only female mites were recorded for the other mite species. Tyrophagus putrescientiae, P. longipilus, S. acarorum, and P. fucorum were less abundant, while $K$. laevis, $K$. americana, and $P$. longanalis were the most abundant. These records of T. putrescientiae, P. fucorum, K. laevis, K. americana, P. longipilus, and S. acarorum are the first for Argentine bumblebees.
\end{abstract}

bumblebees / Argentina / associated mites

\section{INTRODUCTION}

The bumblebees (genus Bombus Latreille) are among the most efficient insect pollinators in natural and agricultural ecosystems; most species are polylectic and depend on pollen and nectar of a great variety of plants (Goulson 2003a; Abrahamovich et al. 2001). These bees are large, robust, and hairy, and they are often variable in their coloration patterns (the most common colors being black, yellow, ferruginous, and white). Bombus is a genus of the family Apidae distributed worldwide, principally in temperate

Corresponding author: M. Maggi,

biomaggi@gmail.com

Manuscript editor: David Tarpy areas of North America and Eurasia (Michener 2007). For the Neotropical region, 42 species occupy a variety of habitats, ranging from sea level to about 4,400 $\mathrm{m}$ in the Andes (Abrahamovich and Díaz 2002). In Argentina, there are eight Neotropical and two introduced European species (Abrahamovich and Díaz 2001; Abrahamovich et al. 2005; Torretta et al. 2006): Bombus (Thoracobombus) atratus, Bombus (T.) bellicosus, Bombus (T.) brasiliensis, Bombus (T.) dahlbomii, Bombus (T.) morio, Bombus (T.) opifex, Bombus (Cullumanobombus) tucumanus, Bombus (C.) baeri, Bombus (Megabombus) ruderatus, and Bombus (Bombus) terrestris. The distribution of these bees is wide; three species ( $B$. atratus, $B$. morio, and $B$. bellicosus) have a broad ecological distribution and are well adapted to changing 
Table I. Mites species (indicated by crosses) infesting Bombus species.

\begin{tabular}{|c|c|c|c|}
\hline Phoretic mite & Host & Site & Reference \\
\hline \multirow[t]{2}{*}{ Kuzinia sp } & B. lapidarius & Denmark & Skou et al. (1963) \\
\hline & B. terrestris & Denmark & Skou et al. (1963) \\
\hline \multirow[t]{7}{*}{ K. laevis } & B. atratus & Argentina & This study \\
\hline & B. morio & Argentina & This study \\
\hline & B. bellicosus & Argentina & This study \\
\hline & B. terrestris & Poland & Chmielewski (1969) \\
\hline & B. lapidarius & Switzerland & Schwarz and Huck (1997) \\
\hline & B. terrestris & Turkey & Canyaka and Kaftanoglu (2006) \\
\hline & B. terrestris & Tasmania & Allen et al. (2007) \\
\hline \multirow[t]{11}{*}{ K. americana } & B. atratus & Argentina & This study \\
\hline & B. morio & Argentina & This study \\
\hline & B. opifex & Argentina & This study \\
\hline & B. impatiens & USA & Goldblatt and Fell (1984) \\
\hline & B. griseocollis & USA & Goldblatt and Fell (1984) \\
\hline & B. bimaculatus & USA & Goldblatt and Fell (1984) \\
\hline & B. nevadensis & USA & Goldblatt and Fell (1984) \\
\hline & B. auricomus & USA & Goldblatt and Fell (1984) \\
\hline & B. terricola & USA & Goldblatt and Fell (1984) \\
\hline & B. perplexus & USA & Goldblatt and Fell (1984) \\
\hline & B. vagans & USA & Delfinado and Baker (1976) \\
\hline \multirow[t]{3}{*}{ T. putrescentiae } & B. atratus & Argentina & This study \\
\hline & B. morio & Argentina & This study \\
\hline & B. opifex & Argentina & This study \\
\hline \multirow[t]{3}{*}{ P. longanalis } & B. atratus & Argentina & This study \\
\hline & B. morio & Argentina & This study \\
\hline & B. bellicosus & Argentina & This study \\
\hline \multirow[t]{16}{*}{ P. longipilus } & B. opifex & Argentina & This study \\
\hline & B. atratus & Argentina & This study \\
\hline & B. bellicosus & Argentina & This study \\
\hline & B. terrícola & Canada; USA & Hunter and Husband (1973) \\
\hline & B. fraternus & Canada; USA & Hunter and Husband (1973) \\
\hline & B. griseocollis & Canada; USA & Hunter and Husband (1973) \\
\hline & B. americanorum & Canada; USA & Hunter and Husband (1973) \\
\hline & B. fervidus & Canada; USA & Hunter and Husband (1973) \\
\hline & B. nevadensis & Canada; USA & Hunter and Husband (1973) \\
\hline & B. bifarius & Canada; USA & Hunter and Husband (1973) \\
\hline & B. bimaculatus & Canada; USA & Hunter and Husband (1973) \\
\hline & B. frigidus & Canada; USA & Hunter and Husband (1973) \\
\hline & B. huntii & Canada; USA & Hunter and Husband (1973) \\
\hline & B. ternarius & Canada; USA & Hunter and Husband (1973) \\
\hline & B. vagans & Canada; USA & Hunter and Husband (1973) \\
\hline & B. affinis & Canada; USA & Hunter and Husband (1973) \\
\hline
\end{tabular}


Table I. (continued)

\begin{tabular}{llll}
\hline Phoretic mite & Host & Site & Reference \\
\hline & B. occidentalis & Canada; USA & Hunter and Husband (1973) \\
B. americanorum & Canada; USA & Hunter and Husband (1973) \\
B. tucumanus & Argentina & This study \\
B. atratus & Argentina & This study \\
B. morio & Argentina & This study \\
B. terrestris & Poland & Chmielewski (1971) \\
B. lapidarius & Poland & Chmielewski (1971) \\
B. agrorum (= B. pastuorum) & Poland & Chmielewski (1971) \\
B. fervidus & Canada; USA & Hunter and Husband (1973) \\
B. terrestris & Denmark & Schouboe (1986) \\
B. lucorum & Denmark & Schouboe (1986) \\
B. atratus & Argentina & This study \\
B. bellicosus & Argentina & This study \\
B. terrestris & Poland & Chmielewski (1971) \\
B. lapidarius & Poland & Chmielewski (1971) \\
B. lucorum & Denmark & Schousboe (1987) \\
B. lapidarius & Switzerland & Schwarz and Huck (1997) \\
B. lapidarius & Switzerland & Schwarz and Huck (1997) \\
B. terrestris & Switzerland & Koulianos and Schwarz (1999) \\
B. terrestris & Turkey & Canyaka and Kaftanoglu (2006)
\end{tabular}

environmental conditions. $B$. atratus is the most abundant and dispersive species presenting a higher climatic and altitudinal tolerance.

Commercial rearing of bumblebee colonies for pollination commenced in the 1980s in Europe (Banda and Paxton 1991; Van den Eijnde et al. 1991), which led to the transport of these bees into new regions and the inherent risk of exporting and introducing different diseases (Morales 2007). Given the ecological and economic importance of these insects, there is now widespread concern over the recent decline in pollinator populations that has been detected in many regions of the world (Fitzpatrick et al. 2007). Causes of this decline are thought to be related to changes in the use of agricultural land, but also to the effects of pesticides, parasites, and pathogens (Goulson 2003b; Williams 2005; Otti and Schmid-Hempel 2007).

Mites have been observed on bumblebees and in their nest for over 150 years (Husband 1968). This ecological association of bumblebees and mites varies in form and complexity, ranging from phoresy to parasitism (O'Connor 1988). From an evolutionary perspective, the phoresy phenomenon is an important point of attention for the scientific community because it could evolve into parasitism (Houck and O'Connor 1991). In some cases, mites are important parasites of bees, and a wide knowledge about its parasitic effects are well-documented (Sammataro et al. 2000). Mite relationships with bees could play an important role in explaining bee decline. For example, in the case of honeybees (Apis mellifera L.), there are several parasitic mites known to damage or kill colonies worldwide (Sammataro et al. 2000).

The subject of bumblebee mites occurring on hosts and in their nests has been studied by Chmielewski (1971, 1977, 1998), O'Connor (1988), Houck and O'Connor (1991), and Chmielewski and Baker (2008). These studies describe the nature of the relationships between mites and European bumblebee hosts. In South 


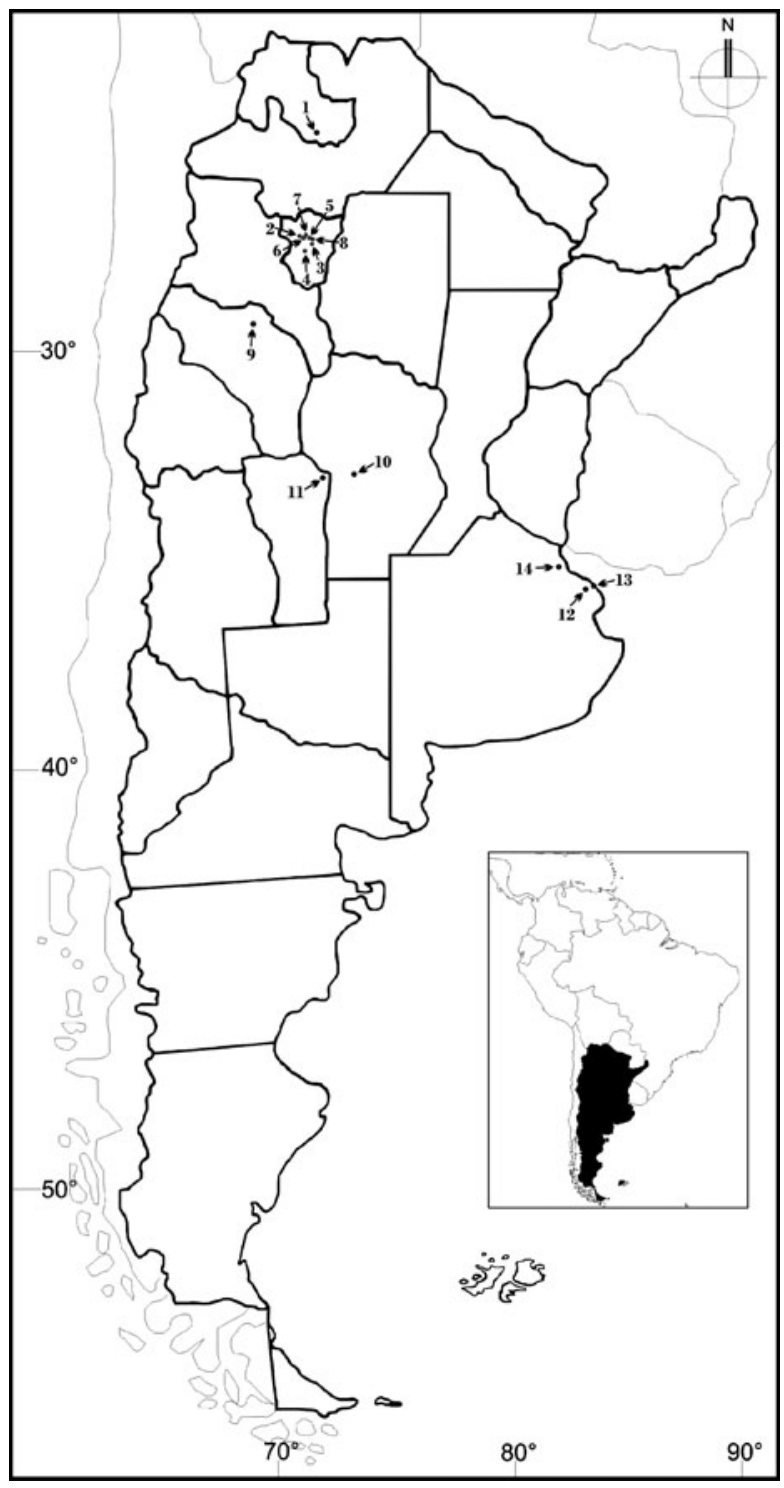

Figure 1. Geographic locations in Argentina where bumblebees were collected. Locations: Jujuy: (1) El Carmen (Ruta 9); Tucumán: (2) El Siambón; (3) El Manantial; (4) La Reducción; (5) Horco Molle; (6) Sala de San Javier; (7) San Javier; (8) Tafi Viejo; La Rioja, (9) Anillaco; Córdoba: (10) Santa Rosa de Calamuchita; San Luis: (11) Merlo (Rincón del Este); Buenos Aires: (12) La Plata; (13) Punta Lara (Camino Negro); (14) San Miguel (Campo de Mayo).

America, there are very few reports of acarofauna in bumblebees, and no comprehensive study has been published; only Eguaras et al. (1997) reported mites associated with B. atratus (Pneumolaelaps longanalis). At present in Argentina, there is a great interest in these studies due to the increase of projects focused on the rearing of natives Bombus colonies for pollination service. 


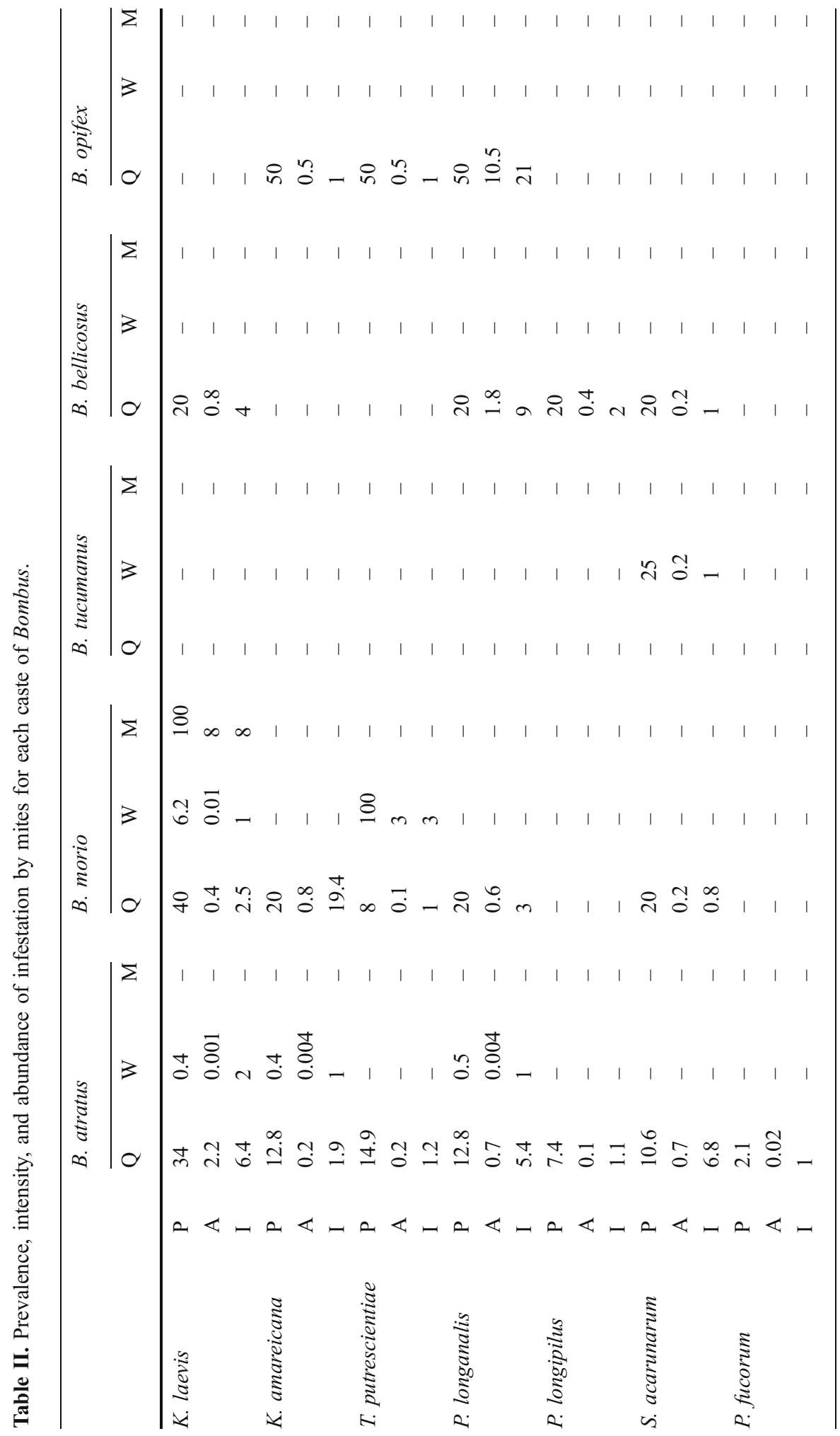


The present research is the first study on the acarofauna associated with the most abundant species of native bumblebees from Argentina, with the purpose to add information about the ecological association between Bombus and mites.

\section{MATERIALS AND METHODS}

Bumblebees were collected using insect nets while foraging on flowers between March 2005 to May 2008 in different regions of Argentina (Jujuy, Salta, Tucumán, La Rioja, San Luis, Córdoba, and Buenos Aires provinces). The sampling included native flora and agricultural crops. Bees and mites were fixed in $70 \%$ alcohol prior to examination. External mites were separated from bees using a stereoscopic microscope, and numbers of mites were counted after removal. Lactic acid $(50 \%)$ was used to fix mites for routine examination and sorting. For mites' identification, specimens were mounted in Oudeman's fluid (as recommended by Hughes 1976) on microscope slides. Bumblebee species were identified with regional taxonomic keys (Abrahamovich et al. 2005), while mite identification was conducted using acarological literature (Zachvatkin
1941; Hunter 1966; Hunter and Husband 1973; Krantz 1978; Putatunda et al. 1983; Fan and Zhang 2007). Abundance, prevalence, and intensity of mite species were recorded for each bumblebee species. The same indices were also used for the mites infesting queens, males, and workers of each Bombus species. For scanning electron microscopy studies, mites were fixed in $2.5 \%$ glutaraldehyde in $0.1 \mathrm{M}$ sodium cacodylate buffer at $\mathrm{pH}$ 7.2-7.4. Mites were dehydrated in a graded alcohol series, dried in hexametildisilazane replacing the critical-point, coated with goldpalladium, and viewed with a JEOL 6460 microscope.

\section{RESULTS}

Mite species, their host Bombus species, and their geographical distribution recorded here and in previous studies are listed in Table I.

\subsection{Hosts}

A total of 382 bumblebee specimens were studied belonging to five species: $B$. atratus $(n=$ 310), B. morio $(n=42), B$. bellicosus $(n=16), B$.

Table III. Prevalence (P), intensity (I), and abundance (A) indices for each mite infesting Bombus species.

\begin{tabular}{lllllllll}
\hline $\begin{array}{l}\text { Bumblebee } \\
\text { species }\end{array}$ & Index & $\begin{array}{l}K . \\
\text { laevis }\end{array}$ & $\begin{array}{l}K . \\
\text { americana }\end{array}$ & $\begin{array}{l}T . \\
\text { putrescientiae }\end{array}$ & $\begin{array}{l}P . \\
\text { longanalis }\end{array}$ & $\begin{array}{l}P . \\
\text { longipilus }\end{array}$ & $\begin{array}{l}S . \\
\text { acarunarum }\end{array}$ & $\begin{array}{l}P . \\
\text { fucorum }\end{array}$ \\
\hline B. atratus & $\mathrm{A}$ & 2.3 & 0.1 & 0.1 & 0.2 & 0.1 & 0.2 & 0.1 \\
& $\mathrm{P}$ & 11.6 & 4.2 & 3.9 & 4.5 & 2.1 & 3 & 0.6 \\
& $\mathrm{I}$ & 19.8 & 4.6 & 1.2 & 5.8 & 7.1 & 6.8 & 1 \\
B. morio & $\mathrm{A}$ & 0.7 & 2.3 & 0.2 & 0.4 & 0 & 0.1 & 0 \\
& $\mathrm{P}$ & 14.3 & 9.5 & 14.2 & 0 & 4.7 & 0 & 0 \\
& $\mathrm{I}$ & 5.2 & 24.2 & 2.3 & 2.7 & 0 & 2 & 0 \\
B. tucumanus & $\mathrm{A}$ & 0 & 0 & 0 & 0 & 0 & 0.1 & 0 \\
& $\mathrm{P}$ & 0 & 0 & 0 & 0 & 0 & 16.7 & 0 \\
& $\mathrm{I}$ & 0 & 0 & 0 & 0 & 0 & 1 & 0 \\
B. bellicosus & $\mathrm{A}$ & 0.7 & 0 & 0 & 2.3 & 0.1 & 0.1 & 0.1 \\
& $\mathrm{P}$ & 12.5 & 0 & 0 & 12.5 & 6.2 & 6.2 & 6.2 \\
& $\mathrm{I}$ & 5.5 & 0 & 0 & 18.5 & 2 & 1 & 2 \\
B. opifex & $\mathrm{A}$ & 0 & 0.1 & 0.1 & 2.6 & 0 & 0 & 0 \\
& $\mathrm{P}$ & 0 & 12.5 & 12.5 & 12.5 & 0 & 0 & 0 \\
& $\mathrm{I}$ & 0 & 1 & 1 & 21 & 0 & 0 & 0 \\
\hline
\end{tabular}


opifex $(n=8)$, and B. tucumanus $(n=6)$. Sampled bumblebees included four males, 249 workers, and 129 queens. A total of 64 specimens of bumblebees were infected with external mites. Figure 1 shows the locations in Argentina where bumblebees infested with mites were found.

\subsection{Composition and prevalence of the acarofauna isolated from native bumblebees of Argentina}

Seven mite species were found to occur in association with the bumblebee fauna of Argentina. Prevalence, intensity, and abundance of mites for each caste of bumblebee species are listed in Table II, and those infesting each bumblebee species are listed in Table III. B. atratus was the only bumblebee where all phoretic mite species were recorded. Figure $2 \mathrm{a}-\mathrm{d}$ shows various phoretic mites attached to different body parts of Bombus.

\subsection{Mites associated with bumble bees}

\subsubsection{Astigmata}

The astigmatids collected were represented mostly by the phoretic dutonymphs (hypopus) of the Acaroidea (Kuzinia): Kuzinia laevis (Dujardin; Figure 3a) and Kuzinia americana (Delfinado and Baker; Figure 3b). Hypopi were characterized by a flattened body with reduced mouthparts (Figure 3c), short legs, and a posterior sucker plate (Figure 3d). Specimens were found principally attached to the lateral sides of scutellum, propodeum, anterior segments of the tergal and sternal metasoma, and below the tegula. They were found lying near
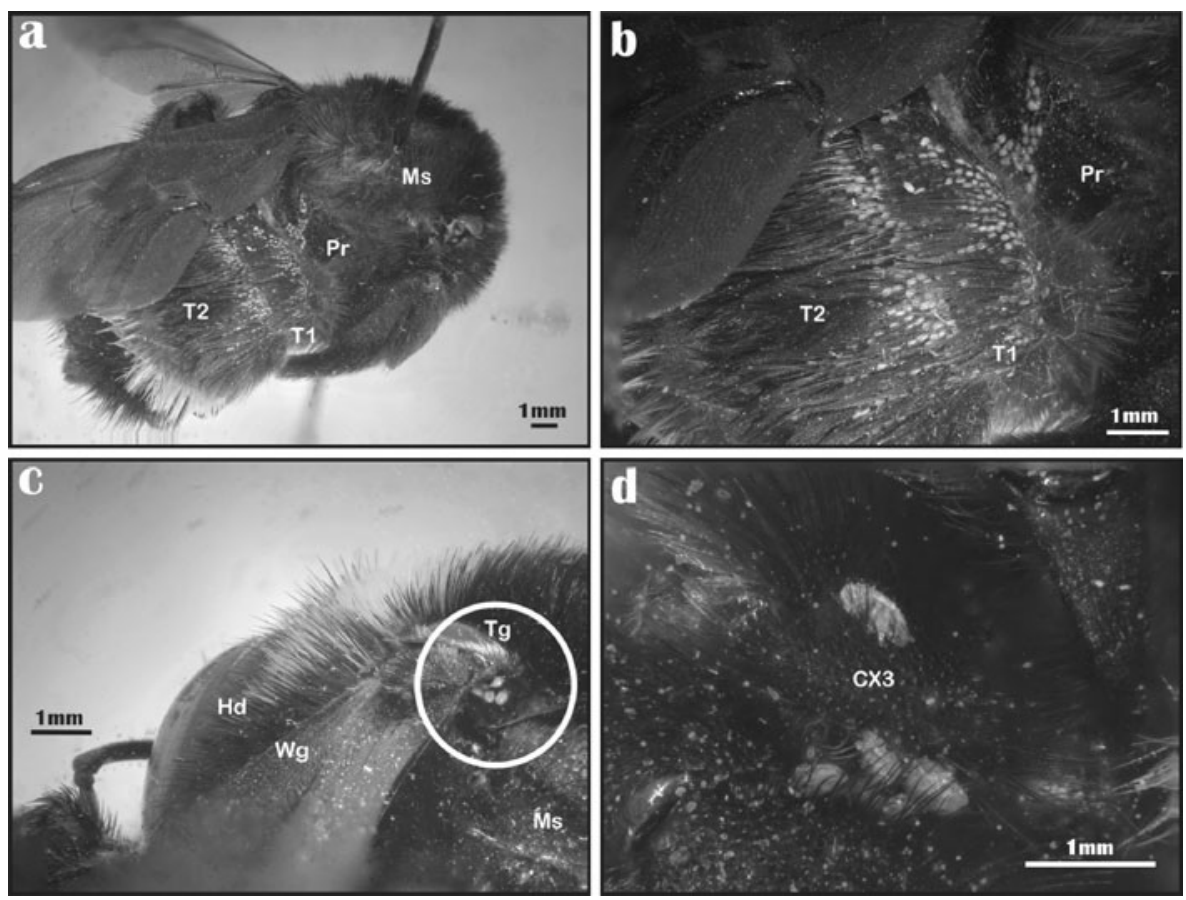

Figure 2. Views of attachments site of phoretic mites: a Kuzinia mites attached on metasomal terga and propodeum of a B. atratus specimen, b detail of (a), c Kuzinia mites attached on metasoma under the tegula of a $B$. atratus specimen, $\mathbf{d}$ B. opifex mites attached on metacoxa. Terms: $M s$ mesosoma, $\operatorname{Pr}$ propodeum, $T 1$ first terga of the metasoma, $T 2$ second terga of the metasoma, $T g$ tegula, $M s$ mesosoma, $W g$ anterior wing, $H d$ head, CX3 metacoxa. 
one another and attached very closely to the body surface with their sucker plates. K. laevis hypopi were found on 45 queens and two worker specimens, while $K$. americana hypopi were found on 17 queens and two workers.

Another astigmatid mite found on bumblebees was Tyrophagus putrescientiae (Acaridae). This mite presents a saccate idiosoma that is whitish to semitransparent. Its dorsum has four pairs of prodorsal setae and 12 pairs of hysterosomal setae, with all of their dorsal setae barbed. These mites were found on 16 queens and one worker bee specimen.

\subsubsection{Heterostigmata}

In the present study, only phoretic scutacarids (Scutacaridae) were found on Bombus, all belonging to Scutacarus acarorum (Goeze;
Figure 4a). Females were found attached on 13 queens and attached in one worker bee. They were rarely found on males and workers. Scutacarid phoretic forms (females) are of small size, strongly sclerotized, have a brown colored idiosoma, and are dorsal-ventrally flattened. Their legs are very short and well adapted for firm attachment to their hosts (Figure $4 b-d)$.

\subsubsection{Mesostigmata}

These large brown mites belong to a very active group. They move rapidly on the body surface of their insect host. Most of the members of this group of mites were identified as Laelapidae: P. longanalis (Hunter and Husband; Figure 5a, c) and Pneumolaelaps longipilus (Hunter; Figure 5b), and Parasitidae: Para-
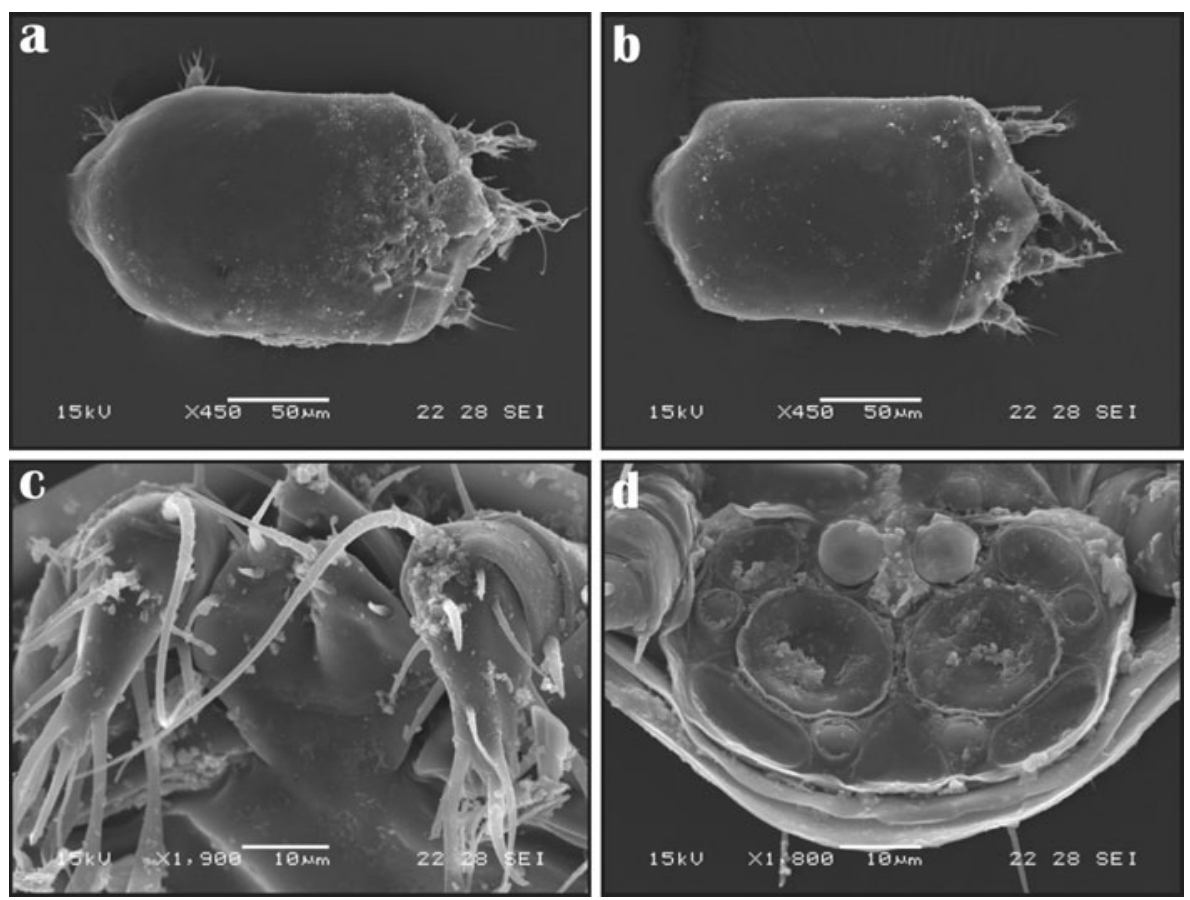

Figure 3. Dorsal and ventral views of the hypopus of Kuzinia spp. (Duj.) from Bombus spp.: a Dorsal view of a $K$. laevis specimen, b dorsal view of a $K$. americana specimen, c reduced mouthparts of a Kuzinia spp. specimen, $\mathbf{d}$ sucker plate on the posterior ventral side of the hypopus of Kuzinia spp. 

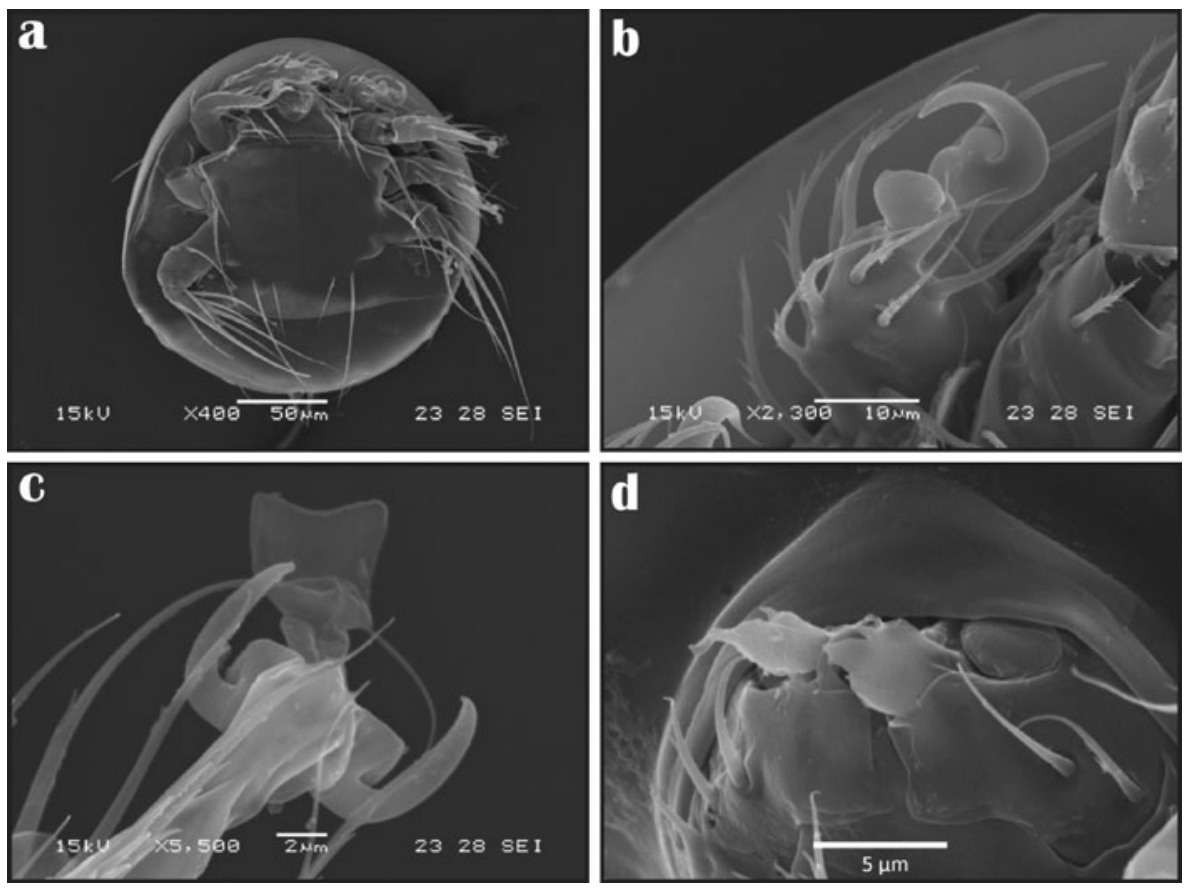

Figure 4. Ventral views of phoretic specimens of S. acarorum (Goeze): a Ventral view of a phoretic female specimen of $S$. acarorum, $\mathbf{b}$ view of the first leg modified in a hook for attachment, $\mathbf{c}$ view of the second leg showing the two claws for attachment, d view of the mouthparts of $S$. acarorum used to feed on the bumblebees' hemolymph.

sitellus fucorum (De Geer; Figure 5d). Mesostigmatid mites were found phoretic on 33 queens and on two workers.

\section{DISCUSSION}

Previous to this study, the acarofauna of the bumblebees of Argentina was poorly known. In the present research, we recorded seven mite species of which six are reported for the first time to be associated with a Bombus species in Argentina. In addition, the results presented here extend their distribution of both their host and geography. The large number of $B$. atratus specimens collected here demonstrates that this species presents a greater abundance and a broader distribution with regard to other bumblebee species.

Considering that $B$. atratus was the only species in which all mites species were recorded, it could be suggested that the mite's "choice" about which bumblebee species to infest could be linked to the great abundance and distribution of this bee because (1) a greater abundance of $B$. atratus may be related to a higher probability of encounter between mite and bee, and (2) the broader distribution of $B$. atratus would allow dispersion of mites to suitable niches.

Mite prevalence was higher for queens than for males and workers, being similar to other studies (Chmielewski 1969, 1971). This situation is related to mite survival and dispersion: in autumn - when the bumblebee colony declines and the workers, males, and the old queen diesmites attach to the young queens that overwinter singly in the soil. When an overwintered queen founds a new colony in spring, adult mites and deutonymphs detach and colonize the new nest (Chmielewski 1971). 

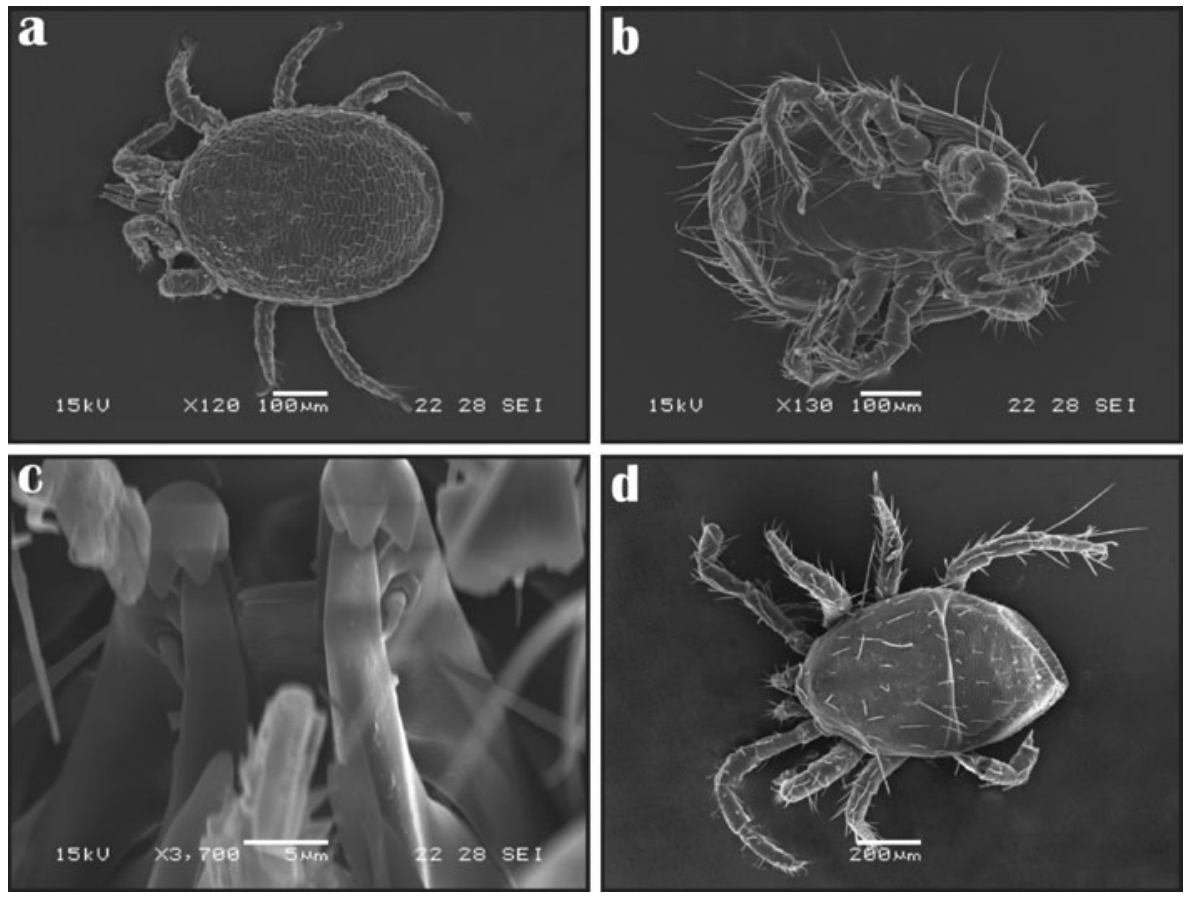

Figure 5. Dorsal and ventral views of phoretic mites representing the Mesostigmata associated with Bombus spp.: a dorsal view of a $P$. longanalis (Hunter and Husband) specimen, b ventral view of a P. longipilus (Hunter) specimen, $\mathbf{c}$ ventral view of the gnathosoma of a $P$. longanalis specimen showing the chelicerae, $\mathbf{d}$ dorsal view a of Parasitellus focurum (De Geer).

Of the seven mite species reported here, only $S$. acarorum mites are parasites of bumblebees; they live and develop in nest material and can use their mouth parts to attach to the bee integument and feed on the hemolymph (Chmielewski 1971). Nevertheless, scutacarid mites (herein $S$. acarorum) also can be fungivorus and suck fluid from fungal hyphae (Ebermann 1991, 1999). In this way, this mite species is not an obligatory parasite of Bombus species but depends on it to ensure its life cycle. Kuzinia mites live, feed, and develop in the nest debris of bumblebees. They feed mainly on pollen, bee-bread, and old combs, and deutonymphs disperse by attaching to adult bumblebees for transport (Chmielewski 1991, 1994). P. fucorum is probably a pollen eater (e.g., pollen grains, bee-bread remains). Depending on the developmental stage, they may also be coprophagous, necrophagous, or a predator of small arthropods (Chmielewski and Baker 2008). The life cycle of $P$. fucorum is typical for mesostigmatic mites and comprises five stages: egg, larva, protonymph, deutonymphs, and adult. The deutonymphs disperse by attaching to adult bumblebees for transport (Huck et al. 1998). Species of the genus Pneumolaelaps feed on pollen and nectar in nests of bumblebees (Royce and Krantz 1989) and, like Kuzinia deutonymphs, they disperse by attaching to adult bumblebees when deleterious ambient conditions in the nest are detected. Eguaras et al. (1997) reported $P$. longanalis mites infesting Bombus in Argentina. Here, we confirm these observations and report co-infestations of $P$. longanalis and $P$. longipilus infesting bumblebees. T. putrescientiae is a cosmopolitan mite associated to stored products (Fan and Zhang 2007) and comprise a group of primarily fungivorous mites, commonly found in stored food products and decaying organic matter. Orantes-Bermejo (2002) reported its presence 
in honeybee colonies, feeding on pollen and honey. The information about Tyrophagus and Pneumolaelaps mites related to bumblebees is scarce, and more studies related to these mites are needed. Kuzinia hypopi hibernate on queen bees, reaching values higher than 200 per bee. Although the relationship between Kuzinia mites and bumblebees was described as phoretic, this large number of mites probably hinders the normal movement and flight of a queen, and, ultimately, may prove harmful for the bumblebee (Chmielewski 1971).

In this study, multi-species assemblage of mites was usually found on a single individual. Associations consisting of up to seven mite species were recorded. This large and diverse mite population on a carrier bee probably enhances the deleterious effect of mite aggregation. Another important point to consider is that mite species reported here eat pollen and honey, and a high number of mites in a bee nest could produce deleterious effects related to the consumption and contamination of bumblebee nest reserves. Nevertheless, mites are not always deleterious (e.g., fungal feeders might help clean food supplies, predators might help to combat harmful parasites; (Okabe and Makino 2008). Many insect hosts clearly have accommodations for phoretic mites (acarinaria). Acarinaria are found in some groups of Hymenoptera (Abrahamovich and de Alzuet AD 1989; O'Connor and Klompen 1999; Okabe and Makino 2003) and are considered one of the best examples of a mutualistic adaptation because they are apparently specialized to shelter mites and exhibit a high specificity between hosts and mites. This hypothesis assumes that associated mites benefit hosts by destroying harmful pathogens or parasites (Eickwort 1994). In this way, future studies should be conducted to test the significance of mite-bumblebee association.

In this research, heteromorphic deutonymphs (=hypopi) of $K$. laevis and $K$. americana and females of Pneumolaelaps were the most abundant mites associated with bumblebees. Although these results were similar to previous studies conducted on $K$. laevis (Chmielewski 1971), no further studies have reported high values of prevalence and abundance for $K$. americana, and P. longanalis. The lesser abundance and intensities of $P$. longipilus, $P$. fucorum, $S$. acarorum, and $T$. putrescentiae suggest that these species are uncommon mites of the acarofauna of bumblebees in Argentina. Nevertheless, more studies to test our observation should be conducted. The research described in this paper has shown that there is an abundant acarofauna associated with Argentine bumblebees, and the relationship between the mites and the bees is diverse and complex. Five mite species were reported for the first time for Argentina, and future studies should be conducted to explain the ecological relationships between each mite species and its host.

\section{ACKNOWLEDGEMENTS}

We thank Consejo Nacional de Investigaciones Científicas y Técnicas de Argentina (CONICET) and Prof. Armando Cicchino (UNMdP, CONICET). We thank two anonymous referees for their criticisms and suggestions.

\section{Etude des espèces d'acariens associées aux bourdons (Bombus) indigènes d'Argentine.}

\section{Argentine / bombus / acari / inventaire espèces / relations interspécifiques}

Zusammenfassung-Untersuchung der Milbenfauna bei den einheimischen Hummelarten (Bombus) in Argentinien. Hummeln gehören zu den effektivsten Bestäubern. In letzter Zeit ist weltweit eine bedrohliche Abnahme bei den Bestäuberpopulationen zu verzeichnen, wobei Parasiten als eine wichtige Ursache für diesen Rückgang vermutet werden. Milben werden bereits seit über 150 Jahren auf Hummeln beobachtet und deren Wechselwirkungen mit den Bienen könnten eine Rolle beim Rückgang von Bienenpopulation spielen. Unter Berücksichtigung der in Argentinien dokumentierten Abnahme der Bienenpopulationen und den spärlichen Informationen über Milben, die Hummeln befallen, wollten wir in dieser Untersuchung die Milbenfauna erfassen, die mit den argentinischen Hummelarten assoziiert ist. Hierfür wurden Hummeln aus unter- 
schiedlichen Regionen Argentiniens mit Insektenkeschern gefangen (Figure 1). Für jede Milbenart wurde die Häufigkeit, Befallsrate und Befallsstärke auf den entsprechenden Hummelarten erfasst, jeweils getrennt für Königinnen, Männchen und Arbeiterinnen (Tables I und II). Insgesamt wurden auf diese Art 382 Hummeln untersucht. Die unterschiedlichen Milbenarten auf diesen Hummeln waren $K$. laevis, $K$. americana (Figure 3), S. acarorum (Figure 4), $P$. longanalis, P. longipilus and P. fucorum (Figure 5), und T. putrescentiae. Milben der Gattung Kuzinia waren als phoretische Formen vertreten (Hypopi). Von $P$. fucorum wurden lediglich Deutonymphen gefunden. Von den anderen Milbenarten wurden ausschließlich weibliche Milben erfasst. T. putrescientiae, P. longipilus, $S$. acarorum und P. fucorum waren im Vergleich $K$. laevis, $K$. americana und $P$. longanalis weniger häufig auf Hummelarten vertreten. T. putrescientiae, P. fucorum, K. laevis, $K$. americana, $P$. longipilus und $S$. acarorum stellen die ersten Nachweise für parasitische Milben auf argentinischen Hummelarten dar. Heteromorphe Deutonymphen (= Hypopi) von $K$. laevis und $K$. americana sowie Weibchen von $P$. longanalis waren in dieser Untersuchung die häufigsten Milbenarten auf Hummeln. Bisher wurden in keiner anderen Studie von solch hohen Häufigkeiten und Befallsraten für $K$. americana and $P$. longanalis berichtet. Die geringere Häufigkeit und Befallsstärke von $P$. longipilus, $P$. fucorum, $S$. acarorum und $T$. putrescentiae lassen vermuten, dass diese Arten nicht zur üblichen Milbenfauna der Hummeln in Argentinien gehören. Wir haben gezeigt, dass es eine abundante Milbenfauna auf argentinischen Hummeln gibt und dass die Beziehungen zwischen diesen Milben und den Bienen vielfältig und komplex ist. In weiteren Untersuchungen sollten die ökologischen Wechselwirkungen zwischen jeder einzelnen Milbenart und ihrem Wirt im Detail erforscht werden.

\section{Hummeln / Argentinien / assoziierte Milben}

\section{REFERENCES}

Abrahamovich, A.H., Bischoff de Alzuet, A.D. (1989) Relaciones foréticas entre ácaros (Acaridae y Chaetodactylidae) e Himenópteros (Anthophoridae, Xylocopinae). Rev. Soc. Ent. Arg. 47(1-4)

Abrahamovich, A.H., Díaz, N.B. (2001) Distribución geográfica de las especies del género Bombus
Latreille (Hymenoptera, Apidae) en Argentina. Rev. Bras. Entomol. 45, 23-26

Abrahamovich, A., Díaz, N. (2002) Neotropical bumble bees (Hymenoptera: Apidae: Bombini). Biota. Colombiana 3, 199-214

Abrahamovich, A.H., Tellería, M.C., Díaz, N.B. (2001) Bombus species and their associated flora in Argentina. Bee World 82, 76-87

Abrahamovich, A., Díaz, N., Lucia, M. (2005) Las especies del género Bombus Latreille en Argentina (Hymenoptera: Apidae). Estudio taxonómico y claves para su identificación. Neotrop. Entomol. 34, 235-250

Allen, G.R., Seeman, O.D., Schmid-Hempel, P., Buttermore, R.E. (2007) Low parasite loads accompany the invading population of the bumblebee, Bombus terrestris in Tasmania. Insectes Soc. 54, 56-63

Banda, H.J., Paxton, R.J. (1991) Pollination of greenhouse tomatoes by bees. Acta Hortic. 288, 194-198

Canyaka, N., Kaftanoglu, O. (2006) An investigation of some diseases and parasites of bumblebees Queens (Bombus terrestris L.) in Turkey. Pak. J. Biol. Sci. 9, 1282-1286

Chmielewski, W. (1969) Observations on the biology of the species Kuzinia laevis (Dujardin, 1849) (Acarina, Acaridae), new to Polish acarofauna. Pol. Pismo. Ent. 39, 603-617

Chmielewski, W. (1971) The mites (Acarina) found on bumble-bees (Bombus Latr.) and in their nests. Ekol. Pol. 19, 57-71

Chmielewski, W. (1977) Results of observations on associations of mites with insects (Acari - Insecta). Bull. Ent. Pol. 47, 59-78

Chmielewski, W. (1991) Trzmielolubny rozkruszek Kuzinia laevis (Duj.) (Acarida, Acaridae) - rozwój i skadanie jaj na pyku zbieranym przez pszczoy. Pszczeln. Zesz. Nauk. 35, 75-82

Chmielewski, W. (1994) Skadanie jaj Irozwój rozkruszków (Acaroidea) na pyku zbieranym przez pszczoy. Pszczeln. Zesz. Nauk. 38, 131-142

Chmielewski, W. (1998) Mites (Acarina) occuring on social bees (Hymenoptera: Apidae: Apinae, Bombinae). Wiad. Entomol. 16, 201-206

Chmielewski, W., Baker, R. (2008) Mites (Acarina) phoretic on some common bumblebee species (Bombus spp.) from the Pulawy area (South-Eastern Poland). J. Apic. Sci. 52, 37-47

Delfinado, M.D., Baker, E.W. (1976) Notes on hypopi (Acarina) associated with bees and wasps (Hymenoptera). N. Y. Entomol. Soc. 84, 76-90

Ebermann, E. (1991) Das Phanomen Polymorphismus in der Milbenfamilie Scutacaridae (Acari, Heterostigmata, Tarsonemina, Scutacaridae). Zoologica 141, 76

Ebermann, E. (1999) Kommentar zu den Schildchenmilben Kärntens (Acari: Heterostigmata: Tarsonemini: Scutacaridae). Natur. Kärn. 15, 543-546

Eguaras, M., Farina, J., Martinez, P.A. (1997) Primera cita del género Pneumolaelaps (Acari: Laelapidae) para la región Neotropical. Rev. Soc. Entomol. Argent. 56, 38 
Eickwort, G.C. (1994) Evolution and life-history patterns of mites associated with bees. In: Houck, M.A. (ed.) Mites, pp. 218-251. Chapman and Hall, New York

Fan, Q.H., Zhang, Z.Q. (2007) Tyrophagus (Acari: Astigmata: Acaridae). Fauna N. Z. 56, 291

Fitzpatrick, U., Murray, T., Paxton, R.J., Breen, J., Cotton, J., Santorum, V., Brown, M.J.F. (2007) Rarity and decline in bumblebees - A test of causes and correlates in the Irish fauna. Biol. Conserv. 136, 185-194

Goldblatt, J., Fell, R. (1984) Parasites and parasitization rates in bumblebee queens. Bombus spp. (Hymenoptera: Apidae) in southwestern Virginia. Environ. Entomol. 13, 1661-1665

Goulson, D. (2003a) Bumblebees: their behavior and ecology. Oxford University Press, Oxford

Goulson, D. (2003b) Effects of introduced bees on native ecosystems. Annu. Rev. Ecol. Evol. Syst. 34, 1-26

Houck, M.A., OConnor, B.M. (1991) Ecological and evolutionary significance of phoresy in the Astigmata. Annu. Rev. Entomol. 36, 611-636

Huck, K., Schwarz, H.H., Schmid-Hempel, P. (1998) Host choice in the phoretic mite Parasitellus fucorum (Mesostigmata: Parasitidae): which bumblebee caste is the best? Oecologia (Berl) 115, 379-384

Hughes, A.M. (1976) The mites of stored food and houses, 2nd edn. Technical Bulletin 9, Ministry of Agriculture, Fisheries and Food, London

Hunter, P.E. (1966) The genus Pneumolaelaps with description of three new species (Acarina: Laelaptidae). J. Kansas. Entomol. Soc. 39, 357-369

Hunter, P.E., Husband, R.W. (1973) Pneumolaelaps (Acarina: Laelapidae) mites from North America and Greenland. Fla. Entomol. 56, 77-91

Husband, R.W. (1968) Acarina associated with Michigan Bombinae. Pap. Mich. Acad. Sci. Arts Lett. 53, 109-112

Koulianos, S., Schwarz, H.H. (1999) Reproduction, development and diet of Parasitellus fucorum (Mesostigmata:Parasitidae), a mite associated with bumblebees (Hymenoptera: Apidae). J. Zool. Lond. 248, 267-276

Krantz, G.W. (1978) A manual of acarology, 2nd edn. Oregon State University Book Stores, Corvallis

Michener, C.D. (2007) The bees of the world, 2nd edn. Johns Hopkins University Press

Morales, C.L. (2007) Introducción de abejorros (Bombus) no nativos: causas, consecuencias ecológicas y perspectivas. Ecología Austral. 17, 51-65

O'Connor, B.M. (1988) Coevolution in astigmatid mitebee associations. In: Needham, G.R., Page, R.P., Delfinado-Baker, R.M., Bowman, C. (eds.) Africanized honey bees and bee mites, pp. 339-346. EllisHorwood Ltd., Chichester, England

O’Connor, B.M., Klompen, J.S.H. (1999) Phylogenetic perspectives on mite-insect associations: the evolution of acarinaria. In: Needam GR, Mitchell R, Horn DJ, Welcourn WC (eds) Acarology IX, vol 2. Symposia, Columbus, Ohio Biology Survey, pp. 63-71

Okabe, K., Makino, S. (2003) Life history of Kurosaia jiju (Acari: Winterschmidtiidae) symbiotic with a mason wasp, Anterhynchium flavomarginatum micado (Hymenoptera:Eumenidae). Ann. Entomol. Soc. Am. 96, 652-659

Okabe, K., Makino, S. (2008) Parasitic mites as parttime bodyguards of a host wasp. Proc. R. Soc. B. 275, 2293-2297

Orantes-Bermejo, F.J. (2002) Acarofauna de las colmenas en España. Vida Apícola 112, 21-24

Otti, O., Schmid-Hempel, P. (2007) Nosema bombi: a pollinator parasite with detrimental fitness effects. J. Invertebr. Pathol. 96, 118-24

Putatunda, B.N., Aggarwal, K., Kapil, R.P. (1983) Two new species of Kuzinia (Acarina: Acaridae) associated with bees (Hymenoptera) from India. Indian. J. Acarol. 8, 57-62

Royce, L.A., Krantz, G.W. (1989) Observations on pollen processing by Pneumolaelaps longanalis (Acari: Laelapidae), a mite associate of bumblebees. Exp. Appl. Acarol. 7, 161-165

Sammataro, D., Gerson, U., Needham, G. (2000) Parasitic mites of honey bees: life history, implications, and impact. Annu. Rev. Entomol. 45, 519-548

Schouboe, C. (1986) On the biology of Scutacarus acarorum Goeze (Acarina: Trombidiformes). Acarologia 27, 151-158

Schousboe, C. (1987) Deutonymphs of Parasitellus phoretic on Danish bumble bees parasitidae, Mesostigmata; Apidae, Hymenoptera). Acarologia 28, 37-41

Schwarz, H.H., Huck, K. (1997) Phoretic mites use flowers to transfer between foraging bumblebees. Insectes. Soc. 44, 303-310

Skou, J.P., Holm, S.N., Haas, H. (1963) Preliminary investigations on diseases in bumble bees (Bombus Latr.). Arsskr. K. Vet. Landbhojsk. (Copenhagen), $27-41$

Torretta, J., Medan, D., Abrahamovich, A. (2006) First record of the invasive bumblebee Bombus terrestris (L.) (Hymenoptera, Apidae) in Argentina. Trans. Am. Entomol. Soc. (Phila) 132, 285-289

Van den Eijnde, J., De Ruijter, A., Van der Steen, J. (1991) Method for rearing Bombus terrestris continuously and the production of bumble bee colonies for pollination purposes. Acta Hortic. 288, $154-158$

Williams, P.H. (2005) Does specialization explain rarity and decline among British bumblebees? A response to Goulson et al. Conserv. Biol. 122, 33-43

Zachvatkin, A.A. (1941) Tiroglifoidnye kleoecei (Tyroglyphoidea). Fauna SSSR 6(1), 475 